TITLE:

\title{
High Performance Protonic Ceramic Fuel Cells with Acid- Etched Surfaces
}

\section{AUTHOR(S):}

Okumura, Yusuke; Nose, Yoshitaro; Katayama, Junichi; Uda, Tetsuya

\section{CITATION:}

Okumura, Yusuke ...[et al]. High Performance Protonic Ceramic Fuel Cells with AcidEtched Surfaces. JOURNAL OF THE ELECTROCHEMICAL SOCIETY 2011, 158(9): B1067B1071

ISSUE DATE:

2011

URL:

http://hdl.handle.net/2433/163419

RIGHT:

(C) 2011 ECS - The Electrochemical Society 


\section{High Performance Protonic Ceramic Fuel Cells with Acid-Etched Surfaces}

Yusuke Okumura, Yoshitaro Nose, Junichi Katayama and Tetsuya Uda

J. Electrochem. Soc. 2011, Volume 158, Issue 9, Pages B1067-B1071. doi: 10.1149/1.3606374
Email alerting Receive free email alerts when new articles cite this article - sign up in service the box at the top right corner of the article or click here

To subscribe to Journal of The Electrochemical Society go to: http://jes.ecsdl.org/subscriptions

(C) 2011 ECS - The Electrochemical Society 


\title{
High Performance Protonic Ceramic Fuel Cells with Acid-Etched Surfaces
}

\author{
Yusuke Okumura, ${ }^{\mathrm{a}}$ Yoshitaro Nose, ${ }^{\text {a Junichi Katayama, }}{ }^{\mathrm{b}}$ and Tetsuya Uda ${ }^{\mathrm{a}, *, \mathrm{z}}$ \\ ${ }^{a}$ Department of Materials Science and Engineering, Kyoto University, Yoshida-Honmachi, Kyoto, 606-8501, Japan \\ ${ }^{b}$ Okuno Chemical Industries Co., Ltd., Osaka, 5380044 Japan
}

\begin{abstract}
We focus on the proton-conducting doped - barium zirconate, which has large proton conductivity at intermediate temperature. We found here a phenomenon that acid - etching of the doped barium zirconate in a solution having a specific $p \mathrm{H}$ leaves a porous structure on the surface, and demonstrated power generation of hydrogen fuel cell using electroless-plated Pd and Pt on the porously acid-etched electrolyte surface. The short circuit current density of the hydrogen fuel cell was about $430 \mathrm{~mA} / \mathrm{cm}^{2}$ at $600^{\circ} \mathrm{C}$ using thick electrolyte of $500 \mu \mathrm{m}$.

(C) 2011 The Electrochemical Society. [DOI: 10.1149/1.3606374] All rights reserved.
\end{abstract}

Manuscript submitted April 27, 2011; revised manuscript received June 8, 2011. Published June 30, 2011.

A secondary battery is considered to be used to level off power generation using natural resources, but it is expensive and a finite battery capacity limits the amount of stored electrical energy; however, if we use fuel as a storing medium for electricity, huge electricity can be stored. Fuel cells are one of the most developed devices for the conversion from fuel to electricity and vice versa. Among them, proton conductor fuel cells have an advantage over oxide ion conductor fuel cells because hydrogen generation in steam electrolysis occurs on another electrode to which steam is fed, which allows high utilization of the fed steam or operation at moderate overpotential in the whole area of the anode. A similar advantage can be recognized in power generation in hydrogen fuel cell operation; that is, the utilization of hydrogen fuel is expected to be higher. A fuel cell using high temperature proton-conducting oxide, ${ }^{1}$ called in the literature PCFC (Protonic Ceramic Fuel Cell), ${ }^{2,3}$ has several benefits over PEMFC(Polymer Electrolyte Membrane Fuel Cell) because PCFC can be operated in an intermediate temperature range of $400-600^{\circ} \mathrm{C}$ to allow to the use of inexpensive catalysts. Representative proton-conducting ceramics are trivalent cation-doped barium zirconates or cerates. ${ }^{4-6}$ These have the highest class conductivity at intermediate temperature among the ceramic ionic conductors. ${ }^{7,8}$ Doped barium zirconates are relatively stable even in an atmosphere containing carbon dioxide, although doped barium cerates decompose by carbon dioxide. ${ }^{9}$ So far, most research on fuel cells using proton-conducting ceramics has focused on doped barium cerates because they were discovered first and making dense electrolyte was easier. Many successful investigations on electrode material for doped barium cerates or solid solutions of zirconate and cerate have been reported. ${ }^{10-13}$ But when applying the same strategy for electrode materials to doped barium zirconates, No attempts have obtained satisfactory results. ${ }^{13-15}$ In our study of an electroless-plating method for yttrium-doped barium zirconate(BZY) we incidentally found that porous structure could be made by just immersing the pellet of BZY in an acid solution at room temperature. This is a quite interesting and useful phenomena to improve the electrode performance of doped barium zirconates. We here introduce this unique approach in detail.

\section{Experimental}

Crystalline powders of $20 \%$ yttrium-doped barium zirconate were prepared by a solid state reaction from barium carbonate $\left(\mathrm{BaCO}_{3}, 99.9 \%\right.$, Wako), zirconia $\left(\mathrm{ZrO}_{2}, 99.97 \%\right.$ including 2 wt \% of hafnium, Tosoh), and yttria $\left(\mathrm{Y}_{2} \mathrm{O}_{3}, 99.9 \%\right.$, Shin-Etsu Chemical) based on the reported method. ${ }^{16,17}$ Raw materials, which were mixed to be $\mathrm{Ba}:(\mathrm{Zr}+\mathrm{Hf}): \mathrm{Y}=1: 0.8: 0.2$, were ball-milled for $24 \mathrm{~h}$ using yttria-stabilized zirconia balls (Tosoh) in isopropyl alcohol and then heated at $1000^{\circ} \mathrm{C}$ for $10 \mathrm{~h}$ in air. The powder was ball-

\footnotetext{
* Electrochemical Society Active Member.

${ }^{\mathrm{z}}$ E-mail: uda.tetsuya.5e@kyoto-u.ac.jp
}

milled for $8 \mathrm{~h}$ and pressed into a pellet at $9.8 \mathrm{MPa}$. The pellet was then heated at $1300^{\circ} \mathrm{C}$ for $10 \mathrm{~h}$ in air. The procedure of ball-milling for $8 \mathrm{~h}$ and heating at $1300^{\circ} \mathrm{C}$ for $10 \mathrm{~h}$ was repeated until only the barium zirconate phase was confirmed by X-ray diffraction analysis (XRD, PANalytical, X'pert Pro, $\mathrm{CuK} \alpha$ ). The pellet was ground into powder, which was then ball-milled for $100 \mathrm{~h}$. It was then mixed with an organic binder solution and pressed into a pellet at 392 MPa. Subsequently, a pellet of about $10 \mathrm{~mm}$ diameter and $1 \mathrm{~mm}$ thickness was heated at $600^{\circ} \mathrm{C}$ for $8 \mathrm{~h}$ to remove the binder solution and then sintered at $1600^{\circ} \mathrm{C}$ for $24 \mathrm{~h}$ in a powder bed $(99 \mathrm{wt} \%$ synthesized barium zirconate and $1 \mathrm{wt} \% \mathrm{BaCO}_{3}$ ) to reduce $\mathrm{BaO}$ loss caused by the high vapor pressure of $\mathrm{BaO}$ and $\mathrm{Ba}(\mathrm{OH})_{2}$ at sintering temperature. We thus obtained a $20 \%$ yttrium-doped barium zirconate (BZY20) pellet. Both surfaces of the sintered pellets were mechanically polished to $500 \mu \mathrm{m}$ thickness. The surface microstructure was observed using a scanning electron microscope (SEM, VE7800; Keyence Corporation).

Then electrolyte was acid-etched to make a porous surface. The pellet after acid-etching was held at $600^{\circ} \mathrm{C}$ in humidified $\mathrm{Ar}$ of $p_{\mathrm{H}_{2} \mathrm{O}}=0.05 \mathrm{~atm}$ for more than $12 \mathrm{~h}$ to saturate it with water, and then cooled to room temperature. Before electroless-plating, the pellet or a half size of pellet was embedded in an alumina ring for mechanical support and sealed with a heat-resistant inorganic adhesive (SUMICERAM S-301, ASAHI Chemical) as seen in Fig. 1. Samples were kept at $150^{\circ} \mathrm{C}$ in air for $1 \mathrm{~h}$ to harden the adhesive. After cooling to room temperature, the lateral side of the alumina ring was masked by vinyl tape and stainless steel wire for a handle was attached to the samples. Electroless-plating was then employed for fabrication of Pd and Pt electrodes. First, the pellets were immersed into pre-cleaning solution containing surfactant to remove organics from the surface, followed by sequential dipping in $\mathrm{Pd} / \mathrm{Sn}$ catalyst solution and Pd or Pt plating solution with de-ionized water washing between steps, as illustrated in Fig. 2. Table I provides basic experimental information, such as the reagent name, a brief explanation of the solution, and the dipping condition. ${ }^{18,19}$

Electrochemical measurements at $600^{\circ} \mathrm{C}$ were conducted on a symmetrical cell of wet $\mathrm{H}_{2}, \mathrm{Pd} / \mathrm{BaZr}_{0.8} \mathrm{Y}_{0.2} \mathrm{O}_{3-\delta}(\mathrm{BZY} 20) / \mathrm{Pd}$, wet $\mathrm{H}_{2}$, and under fuel cell condition of wet $\mathrm{H}_{2}, \mathrm{Pd} / \mathrm{BaZr}_{0.8} \mathrm{Y}_{0.2} \mathrm{O}_{3-\delta} / \mathrm{Pt}$, wet $\mathrm{O}_{2}$.

The water vapor pressure in all experiments was $0.05 \mathrm{~atm}$, and the gas flow rate was $20 \mathrm{ml} \mathrm{min}{ }^{-1}$ hydrogen for the symmetrical cell, and $100 \mathrm{ml} \mathrm{min}^{-1}$ hydrogen or oxygen for the fuel cell condition. For the symmetrical cell, cyclic voltammetry and galvanostatic electrolysis of $330 \mathrm{~mA} / \mathrm{cm}^{2}$ (hydrogen pump) were carried out.

\section{Results and Discussion}

Figure 3 shows microstructures of the surface of BZY20 after immersing it in various acid solutions at room temperature for 30 min, and Fig. 4 provides the weight loss variation of the pellet with time. A well developed porous microstructure was obtained after 


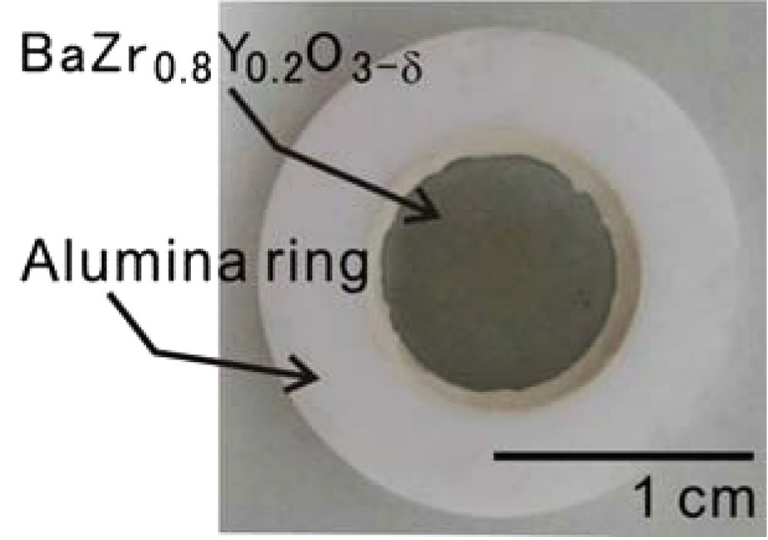

Figure 1. (Color online) Photograph of $\mathrm{BaZr}_{0.8} \mathrm{Y}_{0.2} \mathrm{O}_{3-\delta}$ electrolyte embedded in alumina ring before electroless-plating. immersing the pellet in $85 \% \mathrm{H}_{3} \mathrm{PO}_{4}(p \mathrm{H}=0.76)$ or $50 \% \mathrm{H}_{3} \mathrm{PO}_{2}$ solution $(p \mathrm{H}=1.29)$ for $30 \mathrm{~min}$, but no such porous microstructure was observed after immersing into $35 \% \mathrm{HCl}$ solution $(p \mathrm{H}<0)$. As can be seen in the variation of weight loss, the dissolution rate in $35 \% \mathrm{HCl}$ solution was rapid. Figure 5 is a SEM image of the etched surface of non-doped $\mathrm{BaZrO}_{3}$ after immersing in $85 \% \mathrm{H}_{3} \mathrm{PO}_{4}$ solution at room temperature. This sample was prepared by breaking the sintered block with a hammer, and the obtained surface without mechanical polishing was used to see the difference in the dissolution rate between the grain boundary and the grain interior. It is clear that the grain boundary and the triple junction of grain boundary dissolve preferentially. We therefore conclude that the porous microstructure was obtained as a result of preferential dissolution of the grain boundary. When $p \mathrm{H}$ is lower than around $p \mathrm{H}=1$, no such porous microstructure appeared because of too rapid dissolution rates at both the grain boundary and interior. Of course, when $p \mathrm{H}$ is higher than around $p \mathrm{H}=1$ [as an example, $\left.9 \% \mathrm{H}_{3} \mathrm{PO}_{4}(p \mathrm{H}=1.55)\right]$, clear preferential dissolution was not observed. Preferential dissolution will therefore occur in a specific $p \mathrm{H}$ range. Such preferential dissolution was already reported in barium titanates by Qin et al. ${ }^{20}$

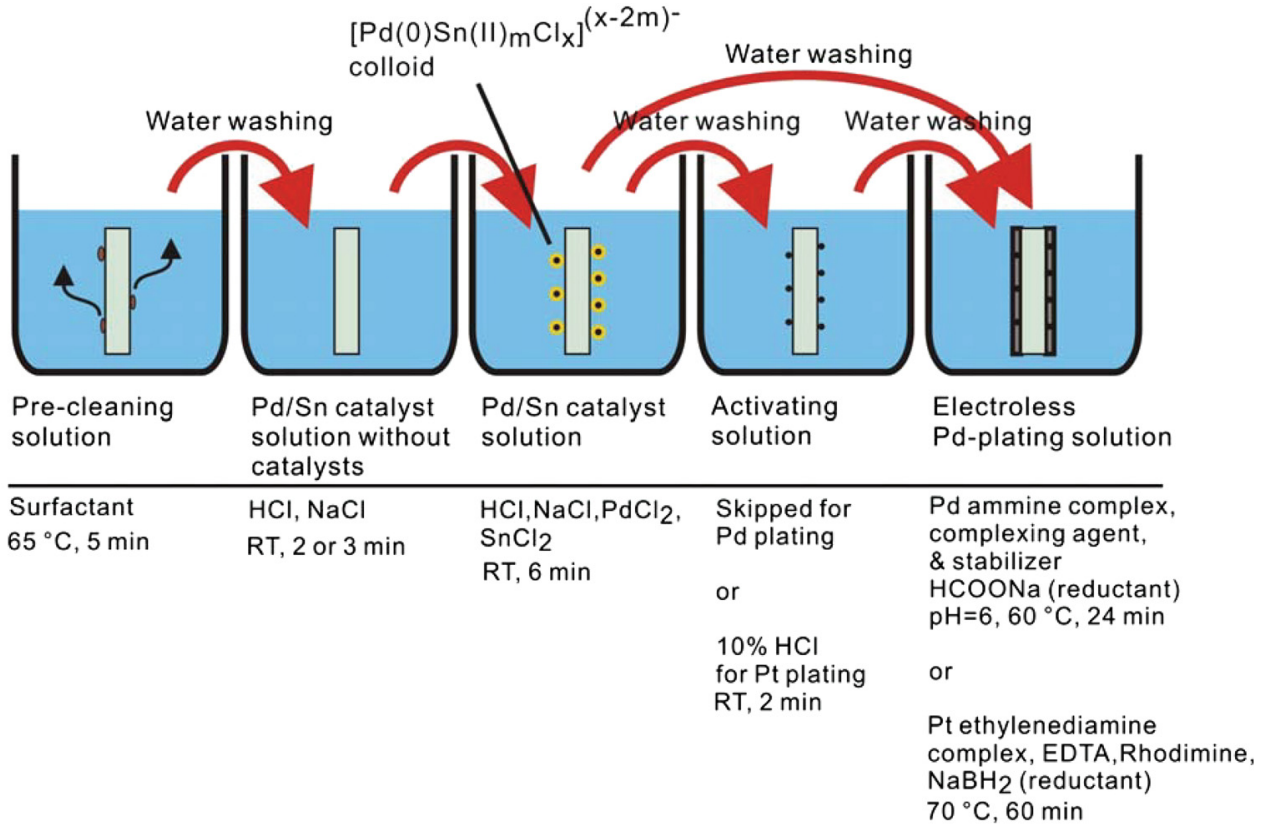

Figure 2. (Color online) Illustration of sequential procedure of electroless-plating of $\mathrm{Pd}$ or $\mathrm{Pt}$ on doped barium zirconate. Usually, an activation step, which involves dipping in a strong acid, is needed between the steps of $\mathrm{Pd} / \mathrm{Sn}$ catalyst solution and electroless Pd-plating solution in order to remove chemically absorbed $\mathrm{Sn}(\mathrm{II})$ ion from metallic $\mathrm{Pd}$ nuclei (explaned by Tsukahara et al.), but it was not needed for Pd plating in this study, although it had an effect on Pt plating. The activation process was dipping in $10 \% \mathrm{HCl}$ solution for $2 \mathrm{~min}$ at room temperature.

\footnotetext{
Table I. Reagents and conditions for electroless-plating of Pd and Pt on doped barium zirconate.

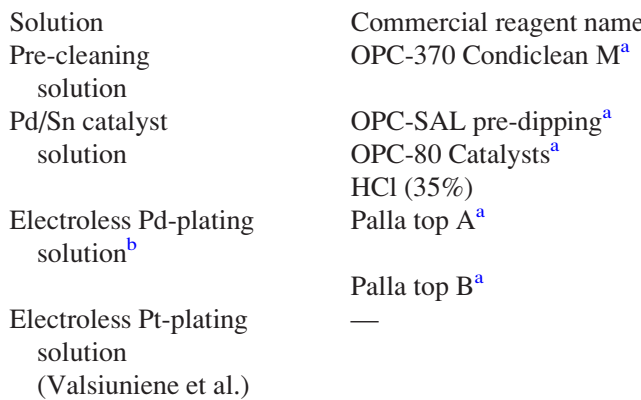

\begin{tabular}{|c|c|}
\hline $\begin{array}{l}\text { Concentration } \\
100 \mathrm{ml} / 1\end{array}$ & $\begin{array}{l}\text { Temp. time } \\
65^{\circ} \mathrm{C} 5 \mathrm{~min}\end{array}$ \\
\hline $170 \mathrm{~g} / 1$ & - \\
\hline $50 \mathrm{ml} / \mathrm{l}$ & $25^{\circ} \mathrm{C} 6 \mathrm{~min}$ \\
\hline $30 \mathrm{ml} / \mathrm{l}$ & - \\
\hline $100 \mathrm{ml} / \mathrm{l}$ & $60^{\circ} \mathrm{C} 24 \mathrm{~min}$ \\
\hline 100 ml/l & - \\
\hline $\begin{array}{l}\mathrm{H}_{2} \mathrm{PtCl}_{6} \cdot 6 \mathrm{H}_{2} \mathrm{O}, \\
\quad 2.64 \mathrm{~g} / \mathrm{lEthylenediamine}, \\
30 \mathrm{~g} / \mathrm{lRhodimine}, \\
0.1 \mathrm{~g} / \mathrm{lNaOH}, \\
10 \mathrm{~g} / \mathrm{INaBH}_{4}, 0.5 \mathrm{~g} / \mathrm{l}\end{array}$ & $70^{\circ} \mathrm{C} 60 \mathrm{~min}$ \\
\hline
\end{tabular}

Main component/note

Surfactant

$\mathrm{NaCl}$

$\mathrm{HCl}, \mathrm{PdCl}_{2}$ and $\mathrm{SnCl}_{2}$

Pd ammine complex, complexing agent, \& stabilizer HCOONa(reductant)

Pt ethylenediamine complex, $\mathrm{NaBH}_{4}($ reductant $)$
}

${ }^{a}$ Supplied by Okuno Chemical Industries Co., Ltd(Japan). ${ }^{\mathrm{b}} \mathrm{pH}$ was controlled to $\mathrm{pH}=6$ by $4 \% \mathrm{HCl}$ and $\mathrm{NaOH}(50 \mathrm{~g} / \mathrm{l})$. 

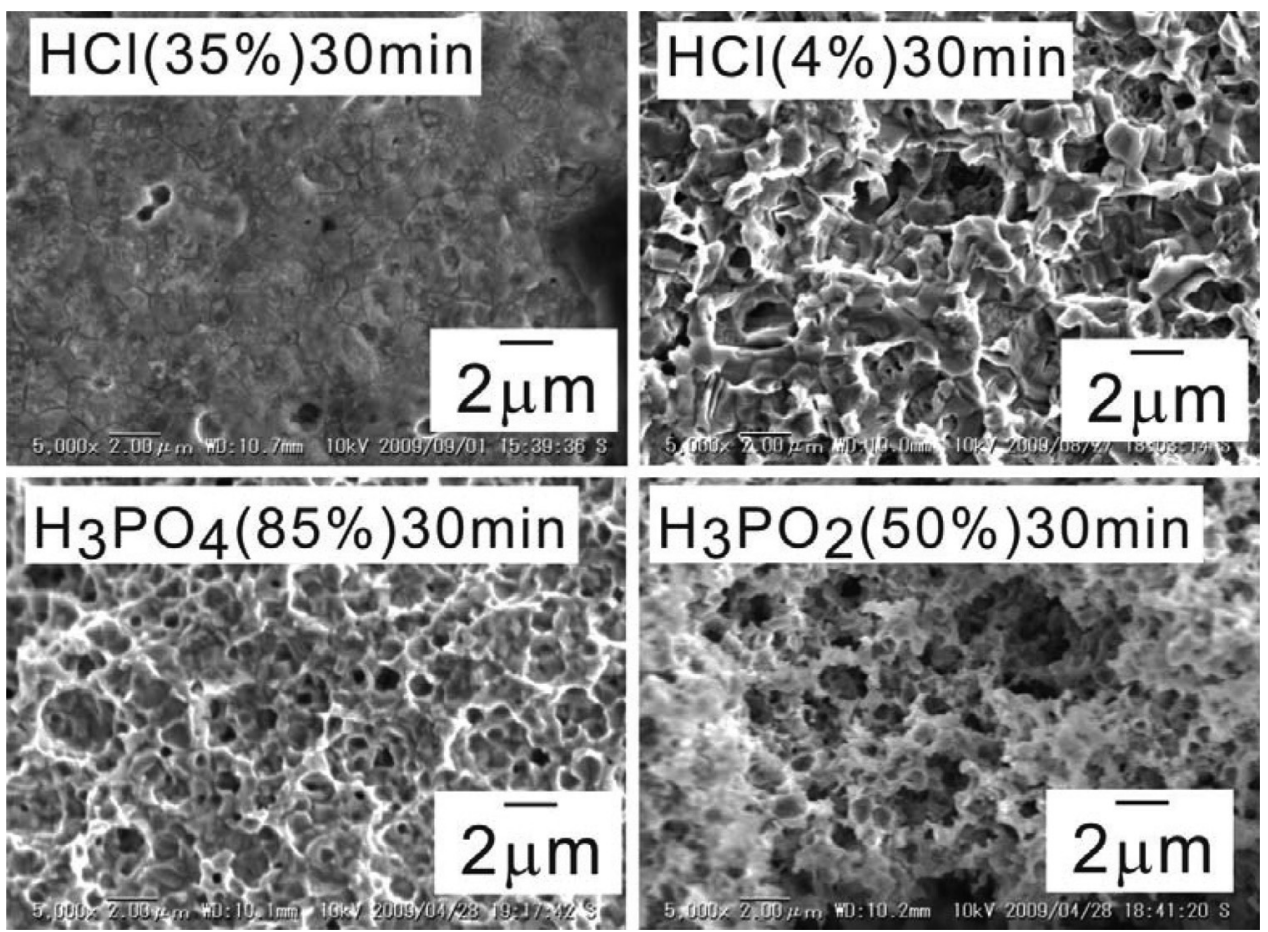

Figure 3. SEM image of surface of $\mathrm{BaZr}_{0.8} \mathrm{Y}_{0.2} \mathrm{O}_{3-\delta}$ pellet after immersing in various acid solutions at room temperature for $30 \mathrm{~min}$
They mentioned that a similar preferential dissolution was observed at around "dislocation" in barium titanate having the form of a cube of several tens nanometers. We also found that $\mathrm{HF}, \mathrm{H}_{2} \mathrm{SO}_{4}$ and $\mathrm{HNO}_{3}$ solutions are difficult to use as etching acids because a secondary phase, $\mathrm{Ba}_{2} \mathrm{ZrF}_{6}, \mathrm{BaSO}_{4}$ or $\mathrm{BaNO}_{3}$, precipitates during etching.

On a pellet, Pd was plated on both surfaces for the symmetrical test (hydrogen pump) in a wet hydrogen atmosphere. On another pellet, Pd and Pt were plated on each surface for the fuel cell test. Figures $6 \mathrm{a}$ and $6 \mathrm{~b}$ are SEM images of $\mathrm{Pd}$ and Pt-plated porous surfaces, respectively. After electroless-plating, good electronic conduction in the planar direction of the Pd-plated sample was confirmed by a multimeter. The resistance between two points was several ohms. On the Pt-plated porous surface we can see the microstructure of the electrolyte, which indicates thin deposition of Pt. In fact, by EDX analysis, no Ba-fluorescent X-ray was observed on the Pdplated surface but a strong Ba-fluorescent X-ray was observed on the Pt-plated surface. Thus, when Pt was electroless-plated, Ag paste was painted on the plated $\mathrm{Pt}$ as a current collector.

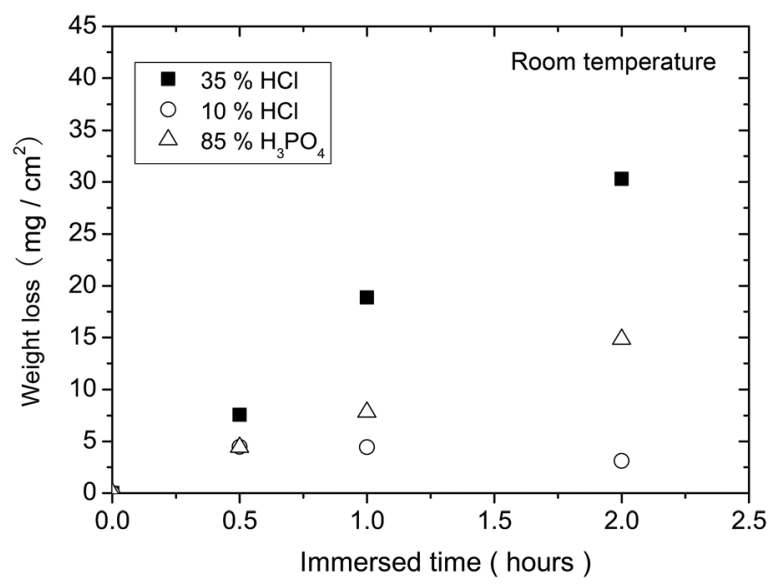

Figure 4. Variation of weight losses of the pellet with time.
The results of cyclic voltammetry in symmetric cell (hydrogen pump cell) after subtracting the IR drop in electrolyte is given as Fig. 7 for comparison between the flat surface (just mechanically polished) and the porous surface after immersing in $85 \% \mathrm{H}_{3} \mathrm{PO}_{4}$.
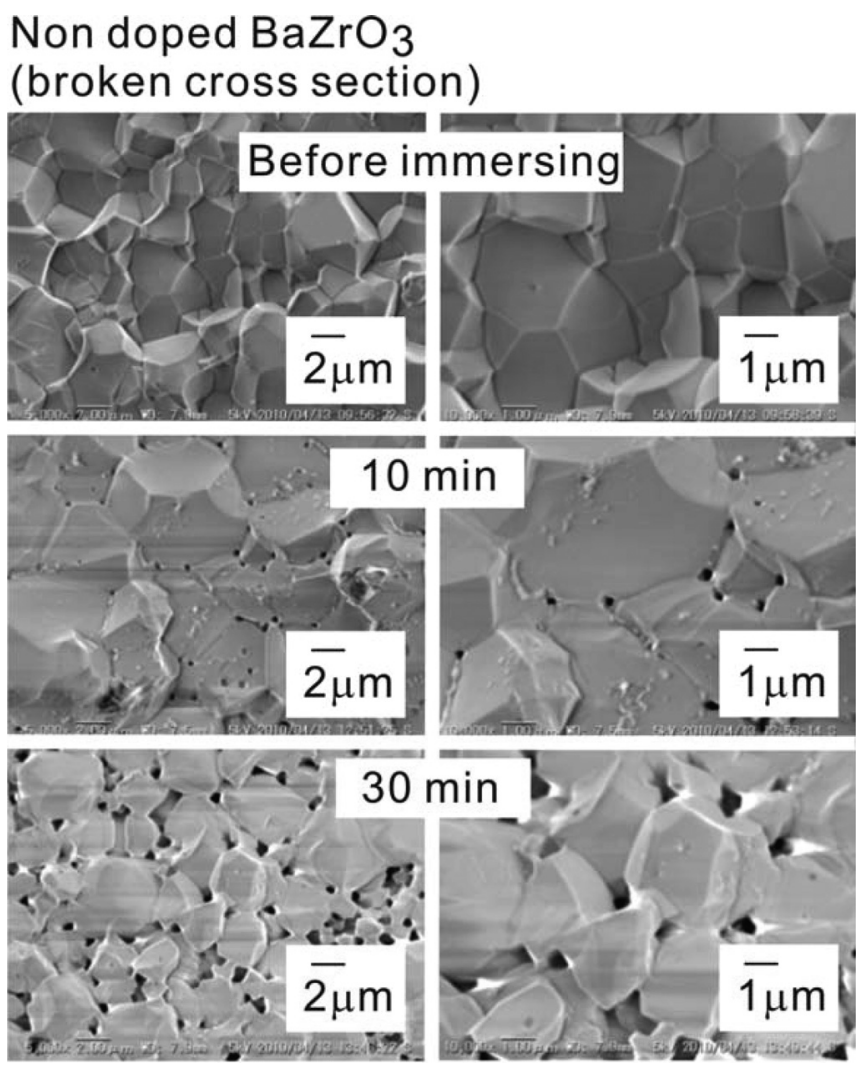

Figure 5. SEM image of cross-section of broken $\mathrm{BaZrO}_{3}$ pellet before and after immersing in $85 \% \mathrm{H}_{3} \mathrm{PO}_{4}$ at room temperature for 10 or $30 \mathrm{~min}$. 
(a)

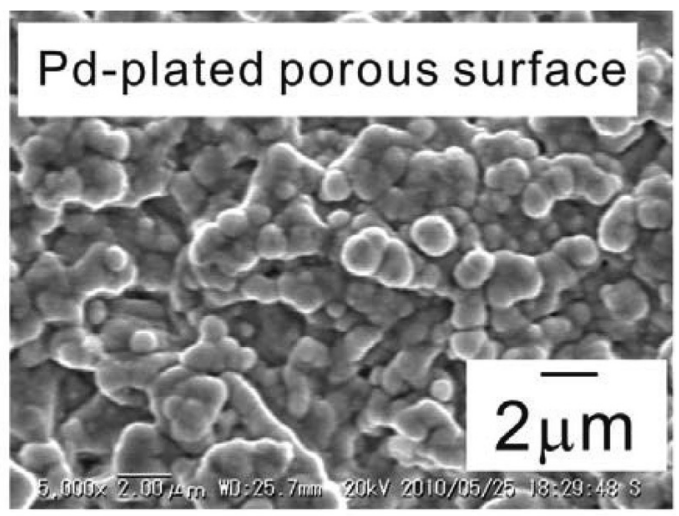

(b)
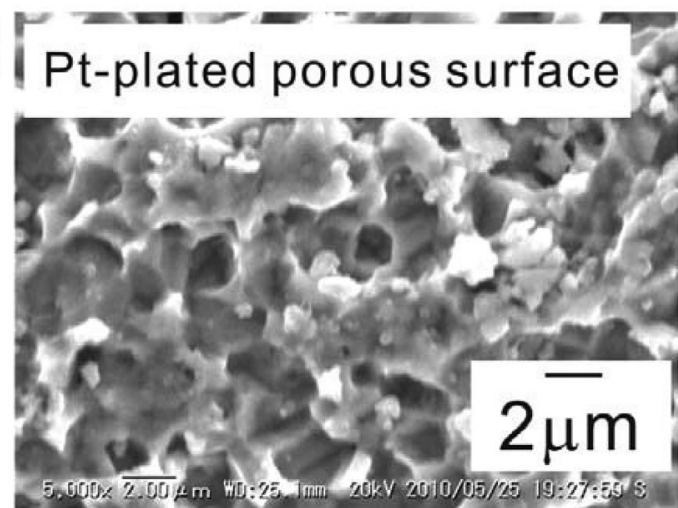

Figure 6. SEM images (a) Pd-plated porous surface (b) Pt-plated porous surface

The electrolyte resistance of each cell was measured by AC impedance analysis. Since linear behavior in a low overpotential region is recognized, the average area-specific resistance, which is the divided slope by two on the assumption of same oxidation and reduction reaction resistance of hydrogen and proton, is evaluated to be $0.7 \Omega \mathrm{cm}^{2}$ for the flat sample and $0.2 \Omega \mathrm{cm}^{2}$ for the porous sample, respectively. Thus, quite a positive effect of the porous microstructure is clearly shown. Figure 8a shows photographs of symmetric cell after the galvanostatic current drawing of $330 \mathrm{~mA} /$ $\mathrm{cm}^{2}$ for $100 \mathrm{~h}$. Delamination of the Pd layer was observed on the flat surface, which was probably caused by shrinkage-sintering of the electroless-plated Pd layer, or the difference in thermal expan-

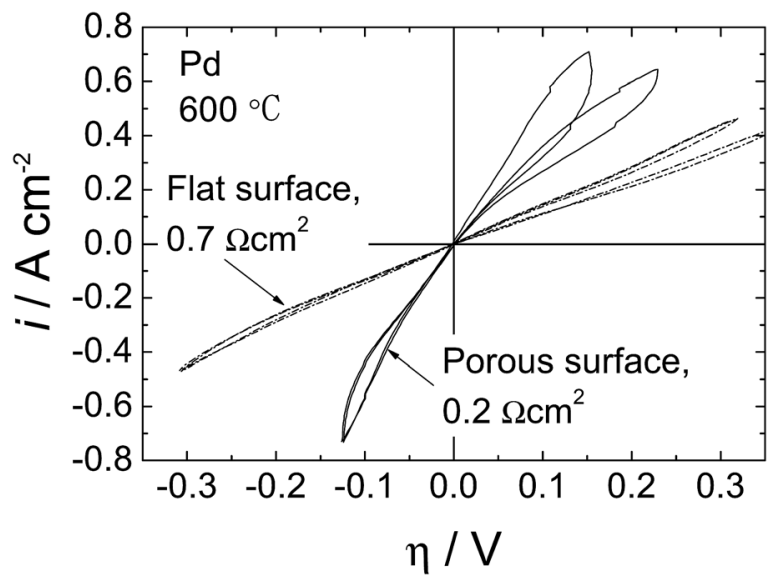

Figure 7. Cyclic voltammograms of symmetrical cell of wet $\mathrm{H}_{2}, \mathrm{Pd} /$ $\mathrm{BaZr}_{0.8} \mathrm{Y}_{0.2} \mathrm{O}_{3-\delta} / \mathrm{Pd}$, wet $\mathrm{H}_{2}$ with flat (just mechanically polished) and porous surface $\left(\boldsymbol{p}_{\mathrm{H}_{2} \mathrm{O}}=0.05 \mathrm{~atm}\right)$. Cyclic voltammograms were measured in the range of the applied voltage of $\pm 2 \mathrm{~V}$ with a scanning rate of $20 \mathrm{mV} \mathrm{s}^{-1}$. (a)

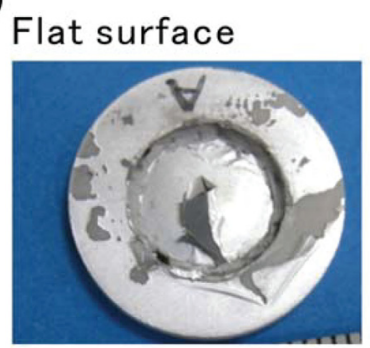

\section{Porous surface}

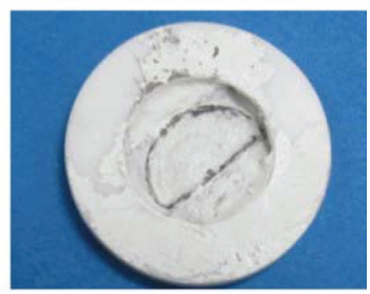

(b)

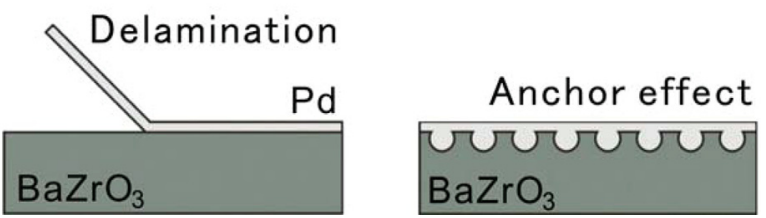

Figure 8. (Color online) (a) Photographs for comparison of plated-Pd after current drawing of $330 \mathrm{~mA} / \mathrm{cm}^{2}$ for $100 \mathrm{~h}$ at $600^{\circ} \mathrm{C}$. (b) Schematic illustration to explain delamination of $\mathrm{Pd}$ on flat surface and anchor effect on porous surface.

sion coefficients, while no such delamination was observed on the porous samples because of anchor effect, as illustrated in Fig. 8b.

Figure 9 is the $\mathrm{I}-\mathrm{V}$ curve of a hydrogen fuel cell at $600^{\circ} \mathrm{C}$. Open circuit voltage of $1050 \mathrm{mV}$, peak power density of $76 \mathrm{~mW} / \mathrm{cm}^{2}$ and short circuit current of $434 \mathrm{~mA} / \mathrm{cm}^{2}$ were achieved. These are the highest class values in reported PCFCs, except the ultrathin membrane fuel cells by Shim et al. ${ }^{21}$ who made the electrode and ultrathin electrolyte by physical deposition methods, such as pulse laser deposition (PLD) and atomic layer deposition (ALD). A freestanding $110 \mathrm{~nm}$ ultrathin electrolyte of doped barium zirconate was fabricated by the ALD process and maximum power density of 136 $\mathrm{mW} / \mathrm{cm}^{2}$ at $400^{\circ} \mathrm{C}$ was reported; however, such an ultrathin membrane is mechanically brittle and difficult to be used in practical applications, and this physical deposition is not suitable for making a thick electrolyte; electrolyte thicker than several tens of microns are expected to have enough mechanical strength to bear the gaseous pressure difference between the anode and cathode, vibration in operation and thermally-induced strains. As another idea, ${ }^{15,22}$ a hydrogen-permeating membrane like $\mathrm{Pd}$ is expected to support the ultrathin electrolyte, but it requires complete elimination of partial oxide ion conduction in doped barium zirconates otherwise water generates at the interface between the electrolyte and Pd membrane,

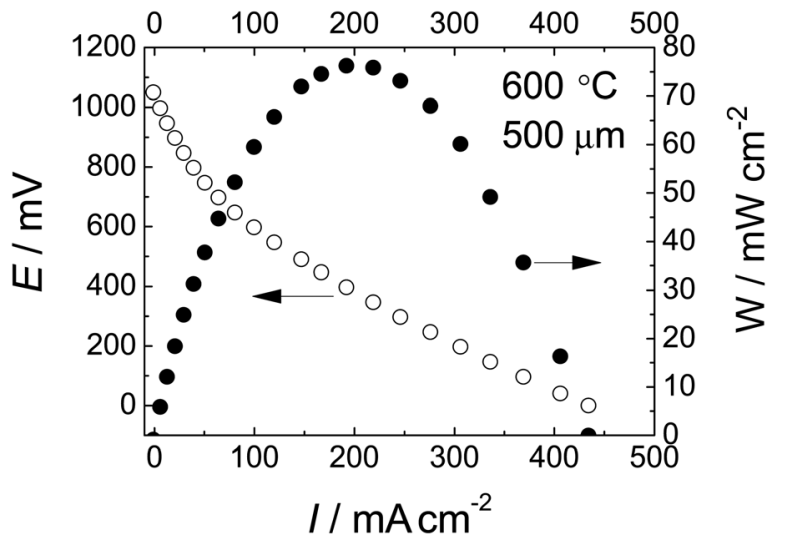

Figure 9. Hydrogen-oxygen fuel cell test at $600^{\circ} \mathrm{C}$. Cathode and anode are electroless-plated $\mathrm{Pt}$ and $\mathrm{Pd}$ on porous $\mathrm{BaZr}_{0.8} \mathrm{Y}_{0.2} \mathrm{O}_{3-\delta}$, respectively. $\mathrm{Ag}$ paste was painted on Pt electrode as current collector. Gas flow rate was 100 $\mathrm{ml} \mathrm{min}{ }^{-1}$ hydrogen or oxygen gas with water vapor pressure of $0.05 \mathrm{~atm}$. Thickness of the electrolyte was $500 \mu \mathrm{m}$. 
and breaks the ultrathin electrolyte; therefore, we expect that the classical ceramic process introduced in this study will work in the fabrication of practical PCFCs.

In our demonstrated fuel cell, relatively large electrode activation loss was recognized in the low current density region (see Fig. 9). This is mainly due to activation loss in the cathode rather than anode; that is, the total voltage drop was $453 \mathrm{mV}$ at the current density of $100 \mathrm{~mA} / \mathrm{cm}^{2}$, and as the electrolyte resistance measured by the AC impedance analysis and area of electrode are $3.8 \Omega$ and $0.6 \mathrm{~cm}^{2}$, the ohmic drop in the electrolyte at $100 \mathrm{~mA} / \mathrm{cm}^{2}$ is calculated to be $228 \mathrm{mV}$. The ovepotential for the anode is estimated to be $20 \mathrm{mV}$ from symmetric measurement; therefore, the contribution by each component to the total voltage drop is calculated as follows: $5 \%$ in anode, $50 \%$ in electrolyte and $45 \%$ in cathode. We used a relatively thick electrolyte of $500 \mu \mathrm{m}$, and thus expect that the electrolyte contribution will be reduced. Thus, new cathode materials and optimization of fabrication process are desired.

\section{Conclusion}

The extensive prevalence of power generation using natural resources such as wind and sunlight has a large impact to save fossil energy, but it causes de-stabilization in the global electric power supply. The leveling off of power generation by installing huge energy storage system is desired to solve the problem. Fuel cells using a proton conductor as an electrolyte are suitable for two-way devices which generate electric power from hydrogen and vice versa. We investigated fuel cells using proton-conducting barium zirconate, and demonstrated power generation of about $76 \mathrm{~mW} / \mathrm{cm}^{2}$ at $600^{\circ} \mathrm{C}$ using electroless-plated electrodes on a porously acidetched electrolyte surface. The fabrication of a porous layer on the doped barium zirconate by acid etching is a novel method and has some benefits, increasing surface area and longevity. There is third benefit; that is, barium zirconate has a refractory nature and for sintering a quite high temperature, typically at around $1600^{\circ} \mathrm{C}$ or higher, is needed; however, vapor loss of $\mathrm{BaO}$ or $\mathrm{Ba}(\mathrm{OH})_{2}$ is not negligible at such a temperature, which causes a marked drop in proton conductivity. ${ }^{7,23,24}$ Mechanical polishing is therefore usually employed to remove the less conductive layer on the surface. Etching can remove this layer.

\section{Acknowledgments}

This study was supported by the Industrial Technology Research Grant Program in 2006 from the New Energy and Industrial Technology Development Organization (NEDO) of Japan. Part of this study was financially supported by the Iwatani Naoji Foundation.

\section{References}

1. H. Iwahara, T. Esaka, H. Uchida, and N. Maeda, Solid State Ionics, 3-4, 359 (1981).

2. W. G. Coors, J. Power Sources, 118, 150 (2003).

3. W. G. Coors, J. Electrochem. Soc., 151, A994 (2004).

4. H. Iwahara, T. Tajima, T. Hibino, K. Ozaki, and H. Suzuki, Solid State Ionics, 61, 65(1993).

5. K. D. Kreuer, Solid State Ionics, 125, 285 (1999).

6. H. G. Bohn and T. Schober, J. Am. Ceram. Soc., 83, 768 (2000).

7. P. Babilio, T. Uda, and S. M. Haile, J. Mater. Res., 22, 1322 (2007).

8. Y. Yamazaki, R. Hernandez-Sanchez, and S. M. Haile, Chem. Mater., 21, 2755(2009).

9. K. H. Ryu and S. M. Haile, Solid State Ionics, 125, 355 (1999).

10. T. Hibino, A. Hashimoto, M. Suzuki, and M. Sano, J. Electrochem. Soc., 149, A1503 (2002).

11. G. Meng, G. Ma, Q. Ma, R. Peng, and X. Liu, Solid State Ionics, 178, 697(2007).

12. L. Bi, S. Zhang, S. Fang, L. Zhang, K. Xie, C. Xia, and W. Liu, Electrochem. Commun., 10, 1005 (2008).

13. Y. Guo, Y. Lin, R. Ran, and Z. Shao, J.Power Sources, 193, 400 (2009).

14. H. Matsumoto and T. Ishihara, J. Surf. Finish. Soc. Jpn., 56, 497 (2005).

15. M. Iijima, N. Ito, S. Matsumoto, and S. Iguchi, Mater. Res. Soc. Symp. Proc., 972 , AA01 (2007).

16. S. Imashuku, T. Uda, and Y. Awakura, Electrochem. Solid-State Lett., 10, B175 (2007).

17. S. Imashuku, T. Uda, Y. Nose, G. Taniguchi, Y. Ito, and Y. Awakura, J. Electrochem. Soc., 156, B1 (2009).

18. M. Tsukahara, M. Tsukahara, T. Kishi, H. Yamamoto, and T. Nagai, J. Met. Finish. Soc. Jpn., 23, 83 (1972).

19. J. Valsiuniene. J.Vinkevicius, and A. Yu. Prokopchik, Liet. TSR Mokslu Akad. Darb., Ser. B, 5, 25 (1976).

20. S. Qin, D. Liu, H. Liu, and Z. Zuo, J. Phys. Chem. C, 112, 17171 (2008).

21. J. H. Shim, J. S. Park, J. An, T. M. Gür, S. Kang, and F. B. Prinz, Chem. Mater. 21, 3290 (2009).

22. N. Ito, M. Iijima, K. Kimura, and S. Iguchi, J. Power Sources, 152, 200 (2005).

23. Y. Yamazaki, R. Hernandez-Sanchez, S. M. Haile, J. Mater. Chem., 20, 8158 (2010).

24. S. Imashuku, T. Uda, Y. Nose, and Y. Awakura, J. Alloys Compd. 509, 3872 (2009). 